\title{
Antepartum Depression and Associated Factors Among Pregnant Women Attending ANC Clinics in Gurage Zone Public Health Institutions, SNNPR, Ethiopia, 2019
}

This article was published in the following Dove Press journal:

Psychology Research and Behavior Management

\section{Solomon Shitu Ayen \\ Selamawit Alemayehu \\ Fentahun Tamene (D) \\ Department of Midwifery, Wolkite University College of Health and Medical Sciences, Wolkite University, Wolkite, Ethiopia}

Background: Antepartum depression is a form of clinical depression that can be caused by the stress and worry that pregnancy can bring a more severe level. It can be triggered by an unplanned pregnancy, a history of substance abuse, and low economic status. Antepartum depression is critical and has an intergenerational impact on children in the developing world and it can have negative effects on fetal development. Therefore, this study aimed to assess its magnitude and associated factors among pregnant women attending antenatal clinics in Gurage zone public health institutions, SNNPR, Ethiopia, 2019.

Methods: Intuition-based cross-sectional study was employed in Gurage zone public health institutions from February 14 to April 14/2019. A systematic random sampling technique was used. The data were collected and then entered into EpiData and processed by SPSS version 24.0 for analysis. $\mathrm{P}$ values $<0.05$ with $95 \%$ confidence level were used to declare statistical significance.

Results: In this study, a total of 343 pregnant mothers were participated by making a response rate of $96 \%$. The magnitude of antepartum depression among pregnant women was $27.6 \%$ (95\% CI: 22.4-33.2). The multivariable analysis showed that respondents who had unplanned pregnancy [AOR=2.11 (95\% CI: 1.05-4.44)], having complications during their previous labor and delivery $[\mathrm{AOR}=4.42$ (95\% CI: 2.06-9.48)], previous history of child hospitalization $[\mathrm{AOR}=3.34(95 \% \mathrm{CI}: 1.48-7.51)]$, and satisfaction in their marriage $[\mathrm{AOR}=3.9$ (95\% CI: 1.15-13.21)] were associated with antepartum depression.

Conclusion: In this study, about one in four women during pregnancy develop antepartum depression. Unplanned pregnancy, complications during labor and delivery of the last baby, women having a history of child hospitalization, and maternal satisfaction with marriage were statistically associated factors with APD. To prevent further consequences, all concerned bodies need to take action by making targeted intervention and early screening of all pregnant mothers for depression.

Keywords: antepartum depression, pregnant women, Guraghe, Ethiopia

\section{Background}

World health organization (WHO) defined depression as a common mental disorder that presents with depressed mood, loss of interest or happiness, decreased energy, feelings of guilt, or low self-worth, disturbed sleep or appetite, and poor concentration. $^{1-3}$ Antepartum depression (APD) is a form of clinical depression that can be caused by the stress and worry that pregnancy can bring more severe
Correspondence: Solomon Shitu Ayen Department of Midwifery, Wolkite

University College of Health and Medical Sciences, Wolkite University, Wolkite 07, Ethiopia

Tel +251924704053

Email solomonsht7@gmail.com 
level. Any form of prenatal stress felt by the mother can have negative effects on various aspects of fetal development, which can cause harm to the mother and child. ${ }^{1,4,5}$

Pregnancy causes significant strain on a women's body like mood changes, memory loss, eating habits, and sleeping changes. ${ }^{1,6}$ Symptoms' of APD are; inability to concentrate, difficulty remembering, feeling emotional, extreme irritability, sleeping too much or not enough or restlessness, extreme or unending fatigue, desire to overeat or, weight loss/gain unrelated to pregnancy, loss of interest in sex, a sense of dread about everything including the pregnancy, feelings of guilt, persistent sadness, thoughts of suicide, or death. ${ }^{2,7,8}$

Antepartum depression can be caused by various reasons including a combination of hormonal changes and psychological disturbances associated with pregnancy. Relationship problems, family or personal history of depression, maternal anxiety, life stress, and lack of social support, unintended pregnancy, domestic violence, low income, single status, previous pregnancy loss are some of the causes. ${ }^{2,9,10}$ Untreated depression in pregnancy has been also associated with poor pregnancy and birth outcomes such as pre-eclampsia, low birth weight, increased risk of premature delivery, postpartum depression. ${ }^{5,11,12}$

Antepartum depression contributes to $1 / 3$ of work absence due to diseases and $1 / 5$ of all primary care visits. It is estimated that $25-35 \%$ of pregnant women have depressive symptoms and that $20 \%$ of them may meet the diagnostic criteria for major depression. According to the WHO, depression is projected to become the second leading contributor to the global burden of disease by $2020 .^{1,13-16}$

In terms of regional distributions, high rates of mental health problems in pregnant women and mothers have been reported from Africa. One in three to one in five women in developing countries, and about one in ten in developed countries, and $13 \%$ of new mothers experience depression. ${ }^{17-20}$

Even though APD is the health problem of the mothers, as knowledge of the investigators, there is limited information in southern Ethiopia and our locality. So, this study is aimed to show the magnitude and factors associated with APD among pregnant mothers who attend ANC in Gurage zone public health institutions, Ethiopia.

\section{Methods}

\section{Study Design, Area, and Period}

An institution-based cross-sectional study was conducted from February 14 to April 14/2019 in Gurage zone public health institutions. The Gurage zone is one of the administrative zones in South Ethiopia. This is located southwest of Addis Ababa. The capital city of the Gurage zone is Wolkite which is located $153 \mathrm{~km}$ from Addis Ababa capital city of Ethiopia. It has 16 districts and 5 town administrations. There are seven hospitals (five public and two nongovernmental) and 72 health centers serving the total population in the zone.

\section{Source Population}

All pregnant women who visit ANC clinic in Gurage zone public health institutions.

\section{Study Population}

All pregnant women who attend ANC clinic in Gurage zone public health institutions during the study period.

\section{Inclusion Criteria}

All pregnant women attending ANC clinic in Gurage zone public health institutions during the data collection period were included.

\section{Exclusion Criteria}

Pregnant women who were seriously ill and unable to respond during the data collection period.

\section{Sample Size Determination}

The sample size was determined by using a single population proportion formula by considering assumptions of the proportion of depression $31.1 \%$ in a study done in Maichew. ${ }^{35}$ A design effect of $5 \%$ at a $95 \%$ CI.

Considering a $10 \%$ non-response rate, the total study subjects were $328+33=361$ pregnant women.

A systematic random sampling technique was used to select pregnant women coming to the Gurage zone public health institutions during the data collection period.

\section{Data Collection Method}

The interviewer-administered questionnaire was prepared in such a way that it includes socio-demographic and economic characteristics, obstetric variables, sex of the last baby, desired sex of the last baby, number of living children by reviewing relevant literature. Before interviewing data collectors gave information about the aim of the study, purposes, possible risks, and benefits, the right and refusal of mothers, and the confidentiality issues. The data were collected by 8 data collectors and supervised by 2 health professionals. 
The data collectors were trained for summation of the result and cut off point whether the women have depressive symptoms or not then if she has depressive symptoms data collectors were informed for health professionals working at ANC unit confidentially and they council her and appoint after a week to see changes.

\section{Dependent Variables}

Antepartum depression.

\section{Independent Variables}

Social demographic variable (age, income, educational status of mothers, husbands' educational status.

Obstetric variable (unplanned pregnancy, mode of delivery, complications during labor and delivery).

Substance abuse (smoke during pregnancy and before pregnancy, khat chewing).

Previous psychiatric history, violence, Social support.

\section{Operational Definitions}

Depressed: Those pregnant mothers who score $\geq 13$ cuts off points of EPDS. From ten EPDS questions each of which has four choices resulting maximum score of 30 and minimum 0 . $^{36}$

Not Depressed: Those pregnant mothers who score $<13$ cuts off point of EPDS. From ten EPDS question's each of which has four choices resulting maximum score of 30 and a minimum of $0 .^{36}$

\section{Data Quality Control}

The questionnaire was designed first in the English language and it was translated to local language Amharic language by a translator and again it was translated back to English. The questionnaire was adopted from different studies in the locality but not validated. A pretest was conducted on $5 \%$ of the total sample size at one health center which is not selected as a study area by data collectors and then the questionnaire was assessed for its clarity and a necessary correction was done accordingly. During data, collection data collectors were supervised by supervisors, and overall activities were controlled by principal investigators, and finally after data collection before entry all collected data were checked for completeness.

\section{Data Processing and Analysis}

Data were coded, cleaned, edited, entered into EpiData version 3.1 to minimize logical errors, and then the data was exported to SPSS version 24 for analysis. Descriptive statistical analysis was carried out to compute frequency and percentage and presented by text and tables. Binary logistic regression analysis was used to ascertain the association between explanatory and outcome variables. Variables with significant $(\mathrm{P}<0.25)$ association in the bivariate analysis were entered into multivariate analysis and those variables with $\mathrm{P}<0.05$ in multivariate analysis were considered to be statistically significant. Finally, the result of the study was presented in texts, tables and it was discussed using the odds ratio and $95 \%$ confidence level.

\section{Results}

\section{Socio-Demographic Characteristics}

In this study, a total of 343 pregnant mothers were participated by making a response rate of $96 \%$. The majority $141(41 \%)$ of respondents were in the age range between 25-29 years old with a mean of $27.3(\mathrm{SD} \pm 5.6)$ years. Out of the total respondents, 142 (41.4\%) were Orthodox followed by Muslim 84 (24.5), protestant 65 (19\%), and catholic 52 (15.2\%). About the educational status of the women $209(60 \%)$ was educated above secondary school. The marital status of the participants $282(82.2 \%)$ was married. More than half $(60.0 \%)$ of the respondents were a housewife and 187 (54.5\%) were urban residents. One hundred thirty-one $(38 \%)$ of the husband's occupation were a merchant. About three fourth 225 participants monthly income was $\leq 1000$ (Table 1).

\section{Obstetric Characteristics of Pregnant Mothers}

Of respondents, $116(33.8 \%)$ were get pregnant two times. Sixty-three percent of the participant's current pregnancy was planned. More than three fourth of participants had no history of abortion. Nearly two-thirds of the participant's previous baby's sex was male. Sixty-five percent of the respondent's place of delivery for the previous pregnancy was spontaneous delivery (Table 2).

\section{Substance Abuse of Pregnant Women}

In this study, $81(23.6 \%)$ of respondents had drunk alcohol before pregnancy, whereas $73(21.3 \%)$ respondents had a history of drinking alcohol during pregnancy. Twentynine $(8.45 \%)$ respondents had a history of smoking before or during pregnancy.

\section{Psychosocial History}

More than half (53.2\%) of respondents had good support from their husbands, most $136(54.4 \%)$ of the respondents 
Table I Sociodemographic Characteristics of Pregnant Women Who Attained Antenatal Care Services in Gurage Zone Public Health Institutions, $2019(n=343)$

\begin{tabular}{|c|c|c|c|}
\hline Variables & Category & Frequency & Percent \\
\hline Age & $\begin{array}{l}\leq 19 \\
20-24 \\
25-29 \\
30-34 \\
35-39 \\
\geq 40\end{array}$ & $\begin{array}{l}18 \\
91 \\
141 \\
53 \\
23 \\
17\end{array}$ & $\begin{array}{l}5.2 \\
26.6 \\
41.1 \\
15.5 \\
6.7 \\
5\end{array}$ \\
\hline Religion & $\begin{array}{l}\text { Orthodox } \\
\text { Catholic } \\
\text { Protestant } \\
\text { Muslim }\end{array}$ & $\begin{array}{l}142 \\
52 \\
65 \\
84\end{array}$ & $\begin{array}{l}41.4 \\
15.2 \\
19 \\
24.5\end{array}$ \\
\hline Marital status & $\begin{array}{l}\text { Married } \\
\text { Single } \\
\text { Divorce } \\
\text { Widowed }\end{array}$ & $\begin{array}{l}282 \\
19 \\
14 \\
28\end{array}$ & $\begin{array}{l}82.2 \\
5.5 \\
4.1 \\
8.2\end{array}$ \\
\hline $\begin{array}{l}\text { Educational status of } \\
\text { the mother }\end{array}$ & $\begin{array}{l}\text { No formal } \\
\text { education } \\
\text { Primary school } \\
(1-8) \\
\text { Secondary } \\
\text { school(9-12) } \\
\text { Diploma and } \\
\text { above }\end{array}$ & $\begin{array}{l}47 \\
87 \\
137 \\
72\end{array}$ & $\begin{array}{l}13.7 \\
25.4 \\
39.9 \\
21\end{array}$ \\
\hline $\begin{array}{l}\text { Occupation of the } \\
\text { mother }\end{array}$ & $\begin{array}{l}\text { Housewife } \\
\text { Merchant } \\
\text { Farmer } \\
\text { Daily labor } \\
\text { Student }\end{array}$ & $\begin{array}{l}208 \\
56 \\
33 \\
23 \\
23\end{array}$ & $\begin{array}{l}60.6 \\
16.3 \\
9.6 \\
6.7 \\
6.7\end{array}$ \\
\hline $\begin{array}{l}\text { Husbands educational } \\
\text { level }\end{array}$ & $\begin{array}{l}\text { No formal } \\
\text { education } \\
\text { Primary school } \\
(1-8) \\
\text { Secondary } \\
\text { school(9-12) } \\
\text { Diploma and } \\
\text { above }\end{array}$ & $\begin{array}{l}40 \\
72 \\
99 \\
71\end{array}$ & $\begin{array}{l}11.7 \\
21 \\
28.9 \\
20.7\end{array}$ \\
\hline $\begin{array}{l}\text { Occupation of the } \\
\text { mother }\end{array}$ & $\begin{array}{l}\text { Gov.t worker } \\
\text { Merchant } \\
\text { Farmer }\end{array}$ & $\begin{array}{l}|3| \\
63 \\
49\end{array}$ & $\begin{array}{l}38 \\
18.4 \\
14.3\end{array}$ \\
\hline $\begin{array}{l}\text { Daily labor } \\
\text { Household income }\end{array}$ & $\begin{array}{l}39 \\
\leq 1000 \\
\geq 2000\end{array}$ & $\begin{array}{l}11.4 \\
225 \\
88\end{array}$ & $\begin{array}{l}74.3 \\
25.8\end{array}$ \\
\hline
\end{tabular}

had satisfied with their relationship with the husband's family. More than half $(63.2 \%)$ of the respondents had no previous history of depression whereas, 84 (24.5\%) of
Table 2 Obstetric Characteristics of Pregnant Women Who Attained Antenatal Care Services in Gurage Zone Public Health Institutions, 2019 ( $n=343)$

\begin{tabular}{|c|c|c|c|}
\hline Variables & Category & Number & Percent \\
\hline Number of gravidities & $\begin{array}{l}\text { One } \\
\text { Two } \\
\text { Three } \\
\text { Four and above }\end{array}$ & $\begin{array}{l}67 \\
116 \\
61 \\
99\end{array}$ & $\begin{array}{l}19.5 \\
33.8 \\
17.8 \\
28.9\end{array}$ \\
\hline $\begin{array}{l}\text { Number ANC follow-ups } \\
\text { on current pregnancy }\end{array}$ & $\begin{array}{l}\text { First visit } \\
\text { Second visit } \\
\text { Third visit } \\
\text { Fourth visit }\end{array}$ & $\begin{array}{l}76 \\
145 \\
100 \\
22\end{array}$ & $\begin{array}{l}22.2 \\
42.3 \\
29.2 \\
6.4\end{array}$ \\
\hline $\begin{array}{l}\text { Number of alive children } \\
(n=277)\end{array}$ & $\begin{array}{l}\text { One } \\
\text { Two } \\
\text { Three and } \\
\text { above }\end{array}$ & $\begin{array}{l}65 \\
100 \\
112\end{array}$ & $\begin{array}{l}23.5 \\
36.1 \\
40.4\end{array}$ \\
\hline History of abortion & $\begin{array}{l}\text { Yes } \\
\text { NO }\end{array}$ & $\begin{array}{l}62 \\
281\end{array}$ & $\begin{array}{l}18.1 \\
81.9\end{array}$ \\
\hline Sex of last baby $(n=277)$ & $\begin{array}{l}\text { Male } \\
\text { Female }\end{array}$ & $\begin{array}{l}173 \\
104\end{array}$ & $\begin{array}{l}62.5 \\
37.5\end{array}$ \\
\hline $\begin{array}{l}\text { Desired sex of the last } \\
\text { baby }(n=277)\end{array}$ & $\begin{array}{l}\text { Male } \\
\text { Female }\end{array}$ & $\begin{array}{l}165 \\
112\end{array}$ & $\begin{array}{l}59.6 \\
40.4\end{array}$ \\
\hline $\begin{array}{l}\text { Mode of delivery for } \\
\text { your last pregnancy } \\
(n=277)\end{array}$ & $\begin{array}{l}\text { Vaginal } \\
\mathrm{C} / \text { section }(\mathrm{C} / \mathrm{S}) \\
\text { Instrumental } \\
\text { delivery }\end{array}$ & $\begin{array}{l}207 \\
27 \\
43\end{array}$ & $\begin{array}{l}74.7 \\
9.7 \\
15.5\end{array}$ \\
\hline $\begin{array}{l}\text { Any complication during } \\
\text { delivery }(n=277)\end{array}$ & $\begin{array}{l}\text { Yes } \\
\text { No }\end{array}$ & $\begin{array}{l}81 \\
196\end{array}$ & $\begin{array}{l}29.2 \\
70.8\end{array}$ \\
\hline $\begin{array}{l}\text { Any of your children } \\
\text { hospitalized }(n=277)\end{array}$ & $\begin{array}{l}\text { YES } \\
\text { NO }\end{array}$ & $\begin{array}{l}50 \\
227\end{array}$ & $\begin{array}{l}18 \\
82\end{array}$ \\
\hline $\begin{array}{l}\text { Was your pregnancy } \\
\text { planned }\end{array}$ & $\begin{array}{l}\text { Yes } \\
\text { NO }\end{array}$ & $\begin{array}{l}237 \\
106\end{array}$ & $\begin{array}{l}69.1 \\
30.9\end{array}$ \\
\hline
\end{tabular}

participants had practiced violence by their husband from those $54.8 \%, 20.2 \%$ and $25 \%$ of respondents had experienced verbal, physical, and both (verbal and physical) abuse in their home respectively (Table 3 ).

\section{Magnitude of Depression}

In this study, the proportion of women who had APD was 91 (26.5\%) with 95\% CI: $22.0-31.3$.

\section{Factors Associated with Antepartum}

\section{Depression}

The result revealed that age, educational level of the women, unplanned pregnancy, mode of delivery, 
Table 3 Psychosocial History of Pregnant Women Who Attained Antenatal Care Services in Gurage Zone Public Health Institutions, $2019(n=343)$

\begin{tabular}{|c|c|c|c|}
\hline Variables & Category & Number & Percent \\
\hline $\begin{array}{l}\text { Any of your relatives } \\
\text { suffered from mental illness }\end{array}$ & $\begin{array}{l}\text { Yes } \\
\text { No }\end{array}$ & $\begin{array}{l}91 \\
252\end{array}$ & $\begin{array}{l}16.6 \\
73.5\end{array}$ \\
\hline $\begin{array}{l}\text { Have you ever experienced } \\
\text { any abuse in your home }\end{array}$ & $\begin{array}{l}\text { Yes } \\
\text { No }\end{array}$ & $\begin{array}{l}84 \\
259\end{array}$ & $\begin{array}{l}24.5 \\
75.5\end{array}$ \\
\hline $\begin{array}{l}\text { What kind of abuse do ever } \\
\text { experience }(n=84)\end{array}$ & $\begin{array}{l}\text { Verbal } \\
\text { Physical } \\
\text { Verbal and } \\
\text { physical }\end{array}$ & $\begin{array}{l}46 \\
17 \\
21\end{array}$ & $\begin{array}{l}54.8 \\
20.2 \\
25\end{array}$ \\
\hline $\begin{array}{l}\text { Are you satisfied with your } \\
\text { marriage }\end{array}$ & $\begin{array}{l}\text { Yes } \\
\text { No } \\
\text { More or less }\end{array}$ & $\begin{array}{l}186 \\
58 \\
99\end{array}$ & $\begin{array}{l}54.2 \\
16.9 \\
28.9\end{array}$ \\
\hline $\begin{array}{l}\text { Does your husband support } \\
\text { you and your pregnancy }\end{array}$ & $\begin{array}{l}\text { Yes } \\
\text { No } \\
\text { More or less }\end{array}$ & $\begin{array}{l}184 \\
78 \\
81\end{array}$ & $\begin{array}{l}53.6 \\
22.7 \\
23.6\end{array}$ \\
\hline $\begin{array}{l}\text { Are you satisfied with your } \\
\text { relationship with your } \\
\text { husband's family }\end{array}$ & $\begin{array}{l}\text { Yes } \\
\text { No } \\
\text { More or less }\end{array}$ & $\begin{array}{l}186 \\
58 \\
99\end{array}$ & $\begin{array}{l}54.1 \\
16.9 \\
29\end{array}$ \\
\hline
\end{tabular}

complication during labor and delivery, child hospitalization, previous history of depression, maternal satisfaction with marriage, violence, and smoking during pregnancy were considered for the multivariate logistic regression model. In multivariable logistic regression unplanned pregnancy, complications during labor and delivery, child hospitalization, and maternal satisfaction with mirage were significantly associated with APD.

The odds of depression are increased by 2.11 times for women who have an unplanned pregnancy than their counterparts. Those pregnant women who have a previous history of any complication during labor and delivery were about four times more at risk of depression than women who had no previous history of complications. Those women who have a history of their child hospitalized were 3.34 times the risk of developing depression than their counterparts and those pregnant women who were not satisfied with their mirage were also 3.9 times more likely to have increased the risk of depression than those women who were satisfied in their marriage (Table 4).

\section{Discussion}

This study showed that $26.5 \%$ of respondents had antepartum depression with 95\% CI: 22.0-31.3. Unplanned pregnancy, complications during delivery, child hospitalization, and maternal satisfaction with mirage were significantly associated with APD.

In this study $26 \%$ of respondents suffer from antepartum depression, the finding was in line with the study done in Gondar $25.8 \% .{ }^{26,33}$ Whereas, the finding of the study is lower than the study done in Maichew (31.1\%) North Ethiopia. ${ }^{21,35}$ The difference might be due to the usage of different tools and sample size. Both studies used a selfreporting questioner of 20 yes-no questions. On the other hand, this figure was higher when compared to other similar studies done in Brazil (14.2\%) Turkey (10.9\%), Debra tabor (11.8\%), and Addis Ababa $(11.7 \%)^{23,24,28,31,32,36}$ This discrepancy might be due to the different tools, assessment period, methods, and the difference in the study area.

This study found that antepartum depression was four times higher among women who are not satisfied with their marriage than those who were satisfied with marriage AOR 3.9, (95\% CI: 1.15-13.21). This result is consistent with the study conducted in Gondar; the Amhara region in Ethiopia. ${ }^{19,22,30,33}$ This might be since during the period of pregnancy and delivery women were handling the situation alone and did not have the needed support from their partner.

Unplanned pregnancy was also associated with higher odds of having postpartum depression AOR 2.11 (95\% CI: 1.0, 4.44). This result was also observed in most of the previous studies carried out in Turkey and northwestern Brazil and Addis Ababa Ethiopia. ${ }^{25,28,31,36}$ This may be because the woman with an unplanned pregnancy may be related to the economic problem and she became stressed due to how she gives care for the newborn and health care.

The women with a previous history of complications during delivery were 4.4 times developed APD than those counterparts AOR 4.42 (95\% CI: 2.06-9.48). This result is consistent with the study conducted in North Ethiopia Maichew. ${ }^{29,34,35}$ This might be because negative life events in the previous history are most influential on an individual's mental status it also might be because they are frightened they might face the same problem on their current labor and delivery as well.

Participants whose baby hospitalized were three times develop APD than those who were not hospitalized $\mathrm{AOR}=3.34$ (95\% CI: 4.8, 7.51). The finding was similar to studies conducted in Brazil, and Debar tabor in Ethiopia. ${ }^{27,28,32}$ This might be due to women who had experienced child hospitalization problems before was 
Table 4 Factors Affecting Pregnant Women Who Attended the ANC Clinic in Gurage Zone Public Health Institutions, 20I9 (n=343)

\begin{tabular}{|c|c|c|c|c|c|c|}
\hline \multicolumn{2}{|l|}{ Types of Variables } & \multicolumn{2}{|l|}{ Depression } & \multicolumn{3}{|l|}{ OR(95\% Cl) } \\
\hline & & Depressed\% & Not Depressed\% & COR & AOR & P-Value \\
\hline Age & $\begin{array}{l}\leq 19 \\
20-24 \\
25-29 \\
30-34 \\
35-39 \\
\geq 40\end{array}$ & $\begin{array}{l}6(6.6) \\
20(22) \\
33(36.3) \\
17(18.70 \\
6(6.6) \\
9(9.9)\end{array}$ & $\begin{array}{l}12(4.8) \\
71(27.2) \\
108(42.9) \\
36(14.3) \\
17(6.7) \\
8(3.2)\end{array}$ & $\begin{array}{l}\text { I } \\
0.16(-1.89-0.9 I) \\
0.82(-1.19-1.4 I) \\
0.4(-2.6 I-0.98) \\
0.26(-0.59-2.8 I) \\
0.15(-2.36-0.12)\end{array}$ & $\begin{array}{l}0.06(-0.99-5.22) \\
0.08(-2.12-6.45) \\
0.32(-5.63-8.56) \\
0.15(-1.24-2.89) \\
0.45(0.02-15.36)\end{array}$ & $\begin{array}{l}0.6 \\
2.2 \\
0.39 \\
5.87 \\
0.91\end{array}$ \\
\hline $\begin{array}{l}\text { The educational level of } \\
\text { women }\end{array}$ & $\begin{array}{l}\text { No formal education } \\
\text { Primary school(I-8) } \\
\text { Secondary school } \\
\text { Diploma and above }\end{array}$ & $\begin{array}{l}16(17.6) \\
21(23.1) \\
26(28.6) \\
28(30.8)\end{array}$ & $\begin{array}{l}31(12.3) \\
66(26.2) \\
111(44) \\
44(17.5)\end{array}$ & $\begin{array}{l}0.88(0.38-2.05) \\
0.376(0.17-0.84) \\
0.258(0.12-0.55) \\
I\end{array}$ & $\begin{array}{l}1.29(0.40-4.14) \\
0.44(0.14-1.38) \\
0.53(0.19-1.53) \\
1\end{array}$ & $\begin{array}{l}0.670 \\
0.158 \\
0.243\end{array}$ \\
\hline Was the pregnancy Planned? & $\begin{array}{l}\text { Yes } \\
\text { No }\end{array}$ & $\begin{array}{l}57(62.6) \\
34(37.4)\end{array}$ & $\begin{array}{l}180(7 \mid .4) \\
72(28.6)\end{array}$ & $\begin{array}{l}\text { I } \\
2.46(1.29-4.66)\end{array}$ & I $2.11(1.0-4.44)^{*}$ & 0.049 \\
\hline $\begin{array}{l}\text { Mode of delivery of last baby } \\
(n=277)\end{array}$ & $\begin{array}{l}\text { Vaginal } \\
\mathrm{C} / \text { section(C/S) } \\
\text { Instrumental }\end{array}$ & $\begin{array}{l}45(61.6) \\
11(15.1) \\
17(23.3)\end{array}$ & $\begin{array}{l}162(79.4) \\
16(7.8) \\
26(12.7)\end{array}$ & $\begin{array}{l}\text { I } \\
2.046(0.79-5.32) \\
2.28(1.05-4.97)\end{array}$ & $\begin{array}{l}\text { I } \\
\text { I.4I(0.44-4.52) } \\
\text { I.I3(0.43-2.99) }\end{array}$ & $\begin{array}{l}0.569 \\
0.805\end{array}$ \\
\hline $\begin{array}{l}\text { Any complication during } \\
\text { delivery }(n=277)\end{array}$ & $\begin{array}{l}\text { Yes } \\
\text { No }\end{array}$ & $\begin{array}{l}35(47.9) \\
38(52.1)\end{array}$ & $\begin{array}{l}46(22.5) \\
158(77.5)\end{array}$ & $\begin{array}{l}3.47(1.8-6.67) \\
I\end{array}$ & $\begin{array}{l}4.42(2.06-9.48)^{*} \\
\text { I }\end{array}$ & 0.000 \\
\hline Previous history of depression & $\begin{array}{l}\text { Yes } \\
\text { No }\end{array}$ & $\begin{array}{l}53(58.2) \\
38(41.8)\end{array}$ & $\begin{array}{l}72(28.2) \\
180(7 \mid .4)\end{array}$ & $\begin{array}{l}1.61(0.91-2.83) \\
I\end{array}$ & $\begin{array}{l}0.67(0.32-1.43) \\
1\end{array}$ & 0.302 \\
\hline $\begin{array}{l}\text { Any children hospitalized } \\
(n=277)\end{array}$ & $\begin{array}{l}\text { Yes } \\
\text { No }\end{array}$ & $\begin{array}{l}2 I(28.8) \\
52(7 \mid .2)\end{array}$ & $\begin{array}{l}86(42.2) \\
118(57.8)\end{array}$ & $\begin{array}{l}1.83(1.94-3.59) \\
\mathrm{I}\end{array}$ & $\begin{array}{l}3.34(I .48-7.5 I)^{*} \\
I\end{array}$ & 0.004 \\
\hline Any abuse in her home & $\begin{array}{l}\text { Yes } \\
\text { No }\end{array}$ & $\begin{array}{l}27(29.7) \\
64(70.3)\end{array}$ & $\begin{array}{l}57(22.6) \\
195(77.4)\end{array}$ & $\begin{array}{l}\text { I.55(0.84-2.86) } \\
\mathrm{I}\end{array}$ & $\begin{array}{l}\text { I.02(0.42-2.48) } \\
\text { I }\end{array}$ & 0.970 \\
\hline Satisfaction on marriage & $\begin{array}{l}\text { Yes } \\
\text { No } \\
\text { More or less }\end{array}$ & $\begin{array}{l}48(52.7) \\
22(24.2) \\
21(23.1)\end{array}$ & $\begin{array}{l}138(54.8) \\
36(14.3) \\
78(31)\end{array}$ & $\begin{array}{l}\text { I } \\
0.33(0.16-0.67) \\
\text { I.38(I.52-3.65) }\end{array}$ & $\begin{array}{l}\text { I } \\
0.49(0.18-1.35) \\
3.9(1.15-13.21)^{*}\end{array}$ & $\begin{array}{l}0.171 \\
0.029\end{array}$ \\
\hline Smoking during pregnancy & $\begin{array}{l}\text { Yes } \\
\text { No }\end{array}$ & $\begin{array}{l}3(3.3) \\
88(96.7)\end{array}$ & $\begin{array}{l}26(10.3) \\
226(89.7)\end{array}$ & $\begin{array}{l}0.15(0.02-1.17) \\
1\end{array}$ & $\begin{array}{l}0.38(0.05-3.19) \\
1\end{array}$ & $0.37 I$ \\
\hline
\end{tabular}

Note: *statistically significant at $\mathrm{p}$-value $\leq 0.05$.

that, they might stress themselves thinking about the current baby might face the same problem. And worrying themselves that, there could be a chance they lose their baby.

Using a cross-sectional study design that hinders the researcher from establishing cause and effect relationship between the possible determinant of antepartum depression and the outcome variable and using EPDS may expose participants to bias.

\section{Conclusion}

More than one in four pregnant women develops APD from those who receive ANC in Gurage zone public health institutions. Unplanned pregnancy, complications during labor and delivery of the previous baby, women having a history of child hospitalization, and maternal satisfaction with marriage were statistically associated factors that determine antepartum depression. This implies APD is a concern of government and other stakeholders to work on this to perform the regular preventive screening during antenatal follow-ups for those pregnant women.

\section{Limitation of the Study}

A cross-sectional study design hinders the researcher from establishing cause and effect relationship between the possible determinants and the outcome of interest.

Institutional study design may not show the real prevalence because there are mothers who did not visit health institution for ANC so minimize the real incidence. 


\section{Abbreviations}

ANC, Antenatal Care; AOR, Adjusted Odds Ratio; APD, Antepartum depression; CI, Confidence Interval; EPDS, Edinburg postnatal depression; PI, Principal investigator; SPSS, Statistical package for social sciences; WHO, World health organization.

\section{Data Sharing Statement}

The datasets used and/or analyzed during the current study available from the corresponding author on reasonable request.

\section{Ethical Consideration and Consent to Participate}

Ethical clearance was obtained from Wolkite University, College of Health and Medical Sciences, Institutional Health Research Ethics Review Committee (IHRERC). A formal letter for permission and support was written to the zonal health department of Gurage from Wolkite University and official permission to undertake the study was obtained and permission to conduct the study was asked. The respondents were informed about the objective, purpose, risks, and benefits of the study and the right to refuse to participate, and then informed written and signed consent was taken. The study posed a low or no more than minimal risk to the study participants. Also, the study did not involve any invasive procedures. Moreover, the confidentiality of information was guaranteed by using code numbers rather than personal identifiers and by keeping the data locked. The study was conducted in accordance with the Declaration of Helsinki.

\section{Consent for Publication}

Not applicable.

\section{Declaration}

The content of the study is solely the responsibility of the authors.

\section{Acknowledgment}

We would like to thank Wolkite University for giving technical support to prepare this research.

We would like to forward our deepest appreciation to in Gurage zone public health office and staff for their special support. Also, special gratitude goes to data collectors and our study participants.

\section{Author Contributions}

All authors made a significant contribution to the work reported, whether that is in the conception, study design, execution, acquisition of data, analysis, and interpretation, or in all these areas; took part in drafting, revising, or critically reviewing the article; gave final approval of the version to be published; have agreed on the journal to which the article has been submitted; and agree to be accountable for all aspects of the work.

\section{Funding}

There is no source of funding for this research. All costs were covered by researchers.

\section{Disclosure}

The authors would like to declare that we have no conflicts of interest for this work.

\section{References}

1. World health organization and World organization of family doctors(Wonca). Integrating Mental Health into a Primary Care-A Global Perspective. Geneva, Switzerland: WHO; 2008.

2. Gelaye B, Lemma S, Deyassa N, et al. Prevalence and correlates of mental distress among working adults in Ethiopia. Clin Pract Epidemiol Mental Health. 2012;8(1):126-133.

3. Kastrup CM. Global mental health secondary publication. Dan Med Bull. 2007;54(1):42-43.

4. Antenatal depression. 2013. Available from: www.nct.org.uk Accessed December 29, 2020.

5. Gurage zone socio-Economic profile Archived 2007-10-07at the Wayback Machine Gurage zone government webpage

6. Prevalence of Anxiety, Depression and Associated Factors among Pregnant Women of Hyderabad, Pakistan NIHPA Author Manuscripts 2009; 55(5).

7. Alem A, Araya M, Melaku Z, Wendimagegn D, Abdulahi A. Mental distress in medical students of Addis Ababa University. Ethiop Med J. 2005;43(3):159-166.

8. Dessa N, Berhane $\mathrm{Y}$, et al. Intimate partner violence and depression among women in rural Ethiopia: a cross-sectional study. Clin Pract Epidemiol Mental Health. 2009;5:8. doi:10.1186/1745-0179-1185-1188

9. Vesga-Lopez, et al. Antepartum depression in Brazile. Tealilo Aende Psychiatry. 2013;65(7):805.

10. Murray J, Lopez AD. The Global Burden of Disease: A Comprehensive Assessment of Mortality Disability from Disease, Injuries, and Risk Factors in 1990 and Projected to 2020. Boston: Harvard School of Public Health, World Health Organization; 1996.

11. Tesfaye A. Prevalence and correlates of mental distress among regular undergraduate students ofHawassa University: a cross-sectional survey. East Afr J Public Health. 2009;6(1):85-94. doi:10.4314/ eajph.v6i1.45755

12. Benett HA, Einarson A, Taddio A, Koren G, Einarson TR. Prevalence of depression during pregnancy: a systematic review. Obstet Gynecol. 2004;103:698-708. doi:10.1097/01.AOG.00001166 89.75396.5f

13. Kebede. D, Alem. A, Rashid E. The prevalence and socio-demographic correlates of mental distress in Addis Ababa, Ethiopia. ActapsychiatricaScandinevica. 1999;100(Suppl.397):5-10. 
14. Audu MD, Tesfaye M, Gurmu S, Mela M. Lifetime prevalence of substance abuse and mental distress among homicide offenders in Jimma prison, Ethiopia. Afr J Appl Psychol. 2008;2(3):15-26.

15. Alem A, Kebede D, Woldesemiat G, Jacobsson L, Kullgren G. The prevalence and socio-demographic correlates of mental distress in Butajira, Ethiopia. Acta Psychiatr Scand Suppl. 1999;(397):48-55.

16. Rich-Edwards JW, Kleinman K, Abrams A, et al. Sociodemographic predictors of antenatal and postpartum depressive symptoms among women in a medical group practice. J Epidemiol Community Health. 2006;60(3):221-227. doi:10.1136/jech.2005.039370

17. BizuGelaye S, Lemma N, YonasBahretibeb M, et al. Prevalence and correlates of mental distress among working adults in Ethiopia. Clin Pract Epidemiol Mental Health. 2012;8:126-133.

18. Demena T, Mossie A, Tesfaye M. Khat chewing and mental distress: a community based study, in Jimma City, Southwestern Ethiopia. Ethiop J Health Sci. 2011;21(1):37-45. doi:10.4314/ejhs.v21i1.69042

19. Fekadu A, Alem A, et al. Utility of the concept of minor depressive disorder: evidence from a largely rural community sample in a developing country setting. J Affect Disord. 2007;104(1-3):111-118. doi:10.1016/j.jad.2007.03.008

20. Dessa N, Berhane Y, et al. Depression among women in rural Ethiopia as related to socioeconomic factors: a community-based study on women in reproductive age groups. Scand J Public Health. 2008;36(6):589-597. doi:10.1177/1403494808086976

21. Marcus M, TaghiYasamy M, van Ommeren M, Chisholm D, Saxena S. Depression: A Global Public Health Concern. WHO Department of Mental Health and Substance Abuse; 2012.

22. Kalifa, D S., Glavin, K., Bjertness, E., et al. Antepartum depression among Turkey woman. Int $J$ Women's Health. 2015;7:677-684. doi:10.2147/IJWH.S81401

23. Hailemariam S, Tessema, F., Asefa, M.et al. The prevalence of depression and associated factors in Ethiopia: findings from the National Health Survey. Int $J$ Ment Health Syst. 2012;6:23. doi:10.1186/1752-4458-6-23

24. World Health Organization, World suicide prevention day 2012. Available from: http://www.who.int/mediacentre/events/annual/ world_suicide_prevention_day/en/. Accessed December 29, 2020.

25. Pantelis C, Hindler CG, Taylor JC. Use and abuse of khat (Catha edulis): a review of the distribution, pharmacology, side effects and a description of psychosis attributed to khat chewing. Pharmacol Med. 1989;19:657-668.
26. Wilson Pamela"Antenataldepression" health.ninemsn.com 4 April 2013

27. Wilder P, Mathys K, Brenneisen R, Kalix P, Fisch HU. Pharmacodynamics and pharmacokinetics of khat: a controlled study. Clin Pharmacol Ther. 1994;5595:556-562.

28. Weyerer S, Gorfer ES, Köhler L, et al. Prevalence and risk factors for depression in non-demented primary care attenders aged 75 years and older. J Affect Disord. 2008;111:153-163. doi:10.1016/j.jad.2008. 02.008

29. Vink D, Aartsen JM, Schoevers AR. Risk factors for anxiety and depression in the elderly: A review. J Affect Disord. 2008;106:29-44. doi:10.1016/j.jad.2007.06.005

30. Teixeira C, Figueiredo B, Conde A, Pacheco A, Costa R. Anxiety and depression during pregnancy in women and men. $J$ Affect Disord. 2009;119:142-148. doi:10.1016/j.jad.2009.03.005

31. Pereira PK, Lovisi GM, Pilowsky DL, Lima LA, Legacy LF. Depression during pregnancy: prevalence and risk factors among women attending a public health clinic in Rio de Janeiro, Brazil. Cad Saude Publica. 2009;25:2725-2736. doi:10.1590/S0102-311X 2009001200019

32. Karacam Z, Ancel G. Depression, anxiety, and influencing factors in pregnancy: a study in a Turkish population. Midwifery. 2009;25:344-356. doi:10.1016/j.midw.2007.03.006

33. Bisetegn TA, Mihretie G, Muche T. Prevalence and predictors of depression among pregnant women in Debretabor town, northwest Ethiopia. PLoS One. 2016;11((9).]). doi:10.1371/journal.pone.01 61108

34. Ayele TA, Azalea T, Alemu K, Abdissa Z, Mulat H, Fekadu A. Prevalence and associated factors of antenatal depression among women attending antenatal care service at Gondar University Hospital, Northwest Ethiopia. PLoS One. 2016;11:5. doi:10.1371/ journal.pone.0155125

35. Tilahun B. Prevalence of antenatal depression and associated factors among pregnant women in Maichew, North Ethiopia. 2016;11:2.

36. Demewoze H Prevalence and associated factors of antenatal depression among women attending antenatal care service at Addis Ababa Ethiopia.
Psychology Research and Behavior Management

\section{Publish your work in this journal}

Psychology Research and Behavior Management is an international, peer-reviewed, open access journal focusing on the science of psychology and its application in behavior management to develop improved outcomes in the clinical, educational, sports and business arenas. Specific topics covered in the journal include: Neuroscience, memory and decision making; Behavior modification and management; Clinical

\section{Dovepress}

applications; Business and sports performance management; Social and developmental studies; Animal studies. The manuscript management system is completely online and includes a very quick and fair peer-review system, which is all easy to use. Visit http://www. dovepress.com/testimonials.php to read real quotes from published authors. 